\title{
COLD SPRING HARBOR SYMPOSIA ON QUANTITATIVE BIOLOGY VOLUME LXXI
}




\section{www.cshl-symposium.org}

Institutions that have purchased the hardcover edition of this book are entitled to online access to the Symposium Web site. Please contact your institution's library to gain access to the Web site. The site contains the full text articles from the 2006 Symposium and the Symposia held in 1998-2005 as well as archive photographs and selected papers from the 62-year history of the annual Symposium.

If a token number is given above, you will need to activate the token to gain access. If you have previously registered and activated your online account for any prior volume without the use of a token, then you do not have to register again.

If you do not have an account number or a token number, or are experiencing access problems, please contact Kathy Cirone, CSHL Press Subscription Manager, at 1-800-843-4388, extension 4044 (Continental U.S. and Canada), 516-422-4100 (All other locations), cironek@cshl.edu, or subscriptionfeedback@symposium.org. 


\section{COLD SPRING HARBOR SYMPOSIA ON QUANTITATIVE BIOLOGY

\author{
VOLUME LXXI
}

\section{Regulatory RNAs}

www.cshl-symposium.org 


\title{
COLD SPRING HARBOR SYMPOSIA ON QUANTITATIVE BIOLOGY VOLUME LXXI
}

\author{
(C)2006 by Cold Spring Harbor Laboratory Press \\ International Standard Book Number 978-0-87969-817-1 (cloth) \\ International Standard Book Number 978-0-87969-818-8 (paper) \\ International Standard Serial Number 0091-7451 \\ Library of Congress Catalog Card Number 34-8174 \\ Printed in the United States of America \\ All rights reserved \\ COLD SPRING HARBOR SYMPOSIA ON QUANTITATIVE BIOLOGY \\ Founded in 1933 by \\ REGINALD G. HARRIS \\ Director of the Biological Laboratory 1924 to 1936 \\ Previous Symposia Volumes
}

I (1933) Surface Phenomena

II (1934) Aspects of Growth

III (1935) Photochemical Reactions

IV (1936) Excitation Phenomena

V (1937) Internal Secretions

VI (1938) Protein Chemistry

VII (1939) Biological Oxidations

VIII (1940) Permeability and the Nature of Cell Membranes

IX (1941) Genes and Chromosomes: Structure and Organization

X (1942) The Relation of Hormones to Development

XI (1946) Heredity and Variation in Microorganisms

XII (1947) Nucleic Acids and Nucleoproteins

XIII (1948) Biological Applications of Tracer Elements

XIV (1949) Amino Acids and Proteins

XV (1950) Origin and Evolution of Man

XVI (1951) Genes and Mutations

XVII (1952) The Neuron

XVIII (1953) Viruses

XIX (1954) The Mammalian Fetus: Physiological Aspects of Development

XX (1955) Population Genetics: The Nature and Causes of Genetic Variability in Population

XXI (1956) Genetic Mechanisms: Structure and Function

XXII (1957) Population Studies: Animal Ecology and Demography

XXIII (1958) Exchange of Genetic Material: Mechanism and Consequences

XXIV (1959) Genetics and Twentieth Century Darwinism

XXV (1960) Biological Clocks

XXVI (1961) Cellular Regulatory Mechanisms

XXVII (1962) Basic Mechanisms in Animal Virus Biology

XXVIII (1963) Synthesis and Structure of Macromolecules

XXIX (1964) Human Genetics

XXX (1965) Sensory Receptors

XXXI (1966) The Genetic Code

XXXII (1967) Antibodies

XXXIII (1968) Replication of DNA in Microorganisms

XXXIV (1969) The Mechanism of Protein Synthesis
XXXV (1970) Transcription of Genetic Material

XXXVI (1971) Structure and Function of Proteins at the Threedimensional Level

XXXVII (1972) The Mechanism of Muscle Contraction

XXXVIII (1973) Chromosome Structure and Function

XXXIX (1974) Tumor Viruses

XL (1975) The Synapse

XLI (1976) Origins of Lymphocyte Diversity

XLII (1977) Chromatin

XLIII (1978) DNA: Replication and Recombination

XLIV (1979) Viral Oncogenes

XLV (1980) Movable Genetic Elements

XLVI (1981) Organization of the Cytoplasm

XLVII (1982) Structures of DNA

XLVIII (1983) Molecular Neurobiology

XLIX (1984) Recombination at the DNA Level

L (1985) Molecular Biology of Development

LI (1986) Molecular Biology of Homo sapiens

LII (1987) Evolution of Catalytic Function

LIII (1988) Molecular Biology of Signal Transduction

LIV (1989) Immunological Recognition

LV (1990) The Brain

LVI (1991) The Cell Cycle

LVII (1992) The Cell Surface

LVIII (1993) DNA and Chromosomes

LIX (1994) The Molecular Genetics of Cancer

LX (1995) Protein Kinesis: The Dynamics of Protein Trafficking and Stability

LXI (1996) Function \& Dysfunction in the Nervous System

LXII (1997) Pattern Formation during Development

LXIII (1998) Mechanisms of Transcription

LXIV (1999) Signaling and Gene Expression in the Immune System

LXV (2000) Biological Responses to DNA Damage

LXVI (2001) The Ribosome

LXVII (2002) The Cardiovascular System

LXVIII (2003) The Genome of Homo sapiens

LXIX (2004) Epigenetics

LXX (2005) Molecular Approaches to Controlling Cancer

Front Cover (Paperback): Petunia images courtesy of R. Jorgensen, University of Arizona. Selected images with permission of the American Society of Plant Biologists. Design by Cat Eberstark, Cold Spring Harbor Laboratory.

Authorization to photocopy items for internal or personal use, or the internal or personal use of specific clients, is granted by Cold Spring Harbor Laboratory Press, provided that the appropriate fee is paid directly to the Copyright Clearance Center (CCC). Write or call CCC at 222 Rosewood Drive, Danvers, MA 01923 (508-750-8400) for information about fees and regulations. Prior to photocopying items for educational classroom use, contact CCC at the above address. Additional information on CCC can be obtained at CCC Online at http://www.copyright.com/

All Cold Spring Harbor Laboratory Press publications may be ordered directly from Cold Spring Harbor Laboratory Press, 500 Sunnyside Boulevard, Woodbury, NY 11797-2924. Phone: 1-800-843-4388 in Continental U.S. and Canada. All other locations: (516) 422-4100. FAX: (516) 422-4097. E-mail: cshpress@cshl.edu. For a complete catalog of all Cold Spring Harbor Laboratory Press publications, visit our World Wide Web Site http://www.cshlpress.com/

Web Site Access: Institutions that have purchased the hardcover edition of this book are entitled to online access to the companion Web site at www.cshl-symposium.org. For assistance with activation, please contact Kathy Cirone, CSHL Press Subscription Manager, at cironek@cshl.edu. 


\section{Symposium Participants}

ABAD, XABIER, Dept. of Gene Therapy and Hepatology, Centro de Investigación Médica Aplicada, Universidad de Navarra, Pamplona, Spain

AcH, RoBert, Agilent Laboratories, Agilent Technologies, Palo Alto, California

Adams, Christopher, Dept. of Gene Expression Profiling, Invitrogen Life Technologies, Carlsbad, California

AfoninA, IRINA, Dept. of Research and Development, Nanogen, Bothell, Washington

Ahn, Jeonghyun, Dept. of Microbiology, University of Ulsan College of Medicine, Seoul, South Korea

AIBA, HiROJ, Div. of Biological Science, Graduate School of Science, Nagoya University, Nagoya, Japan

Aigner, Stefan, Lab. of Genetics, The Salk Institute, La Jolla, California

AizAWA, YASUNORI, Center for Biological Resources and Informatics, Tokyo Institute of Technology, Yokohama, Japan

Aksoy, Canan, Cold Spring Harbor Laboratory, Cold Spring Harbor, New York

AlvarEz-SAavedra, Ezequiel, Dept. of Biology, Massachusetts Institute of Technology, Cambridge, Massachusetts

Aman, Pierre, Dept. of Pathology, Sahlgrenska Academy, Göteborg University, Gothenburg, Sweden

AmAral, PAUlo, Dept. of Biochemistry, Institute of Chemistry, University of São Paulo, São Paulo, Brazil

Amariglio, NinetTe, Institute of Hematology, Sheba Medical Center, Tel Hashomer, Israel

Ameres, Stefan, Max F. Perutz Laboratories, Medical University of Vienna, Vienna, Austria

Anderson, EMILY, Dept. of Biology Research and Development, Dharmacon, Lafayette, Colorado

Andersson, MatTiAs, Dept. of Pathology, Lundberg Laboratory for Cancer Research, Göteborg University, Gothenburg, Sweden

Andino, RaUl, Dept. of Microbiology and Immunology, University of California, San Francisco

ANDRUSS, BERNARD, Dept. of Discovery, Asuragen, Austin, Texas

Ansel, K. MARK, CBR Institute for Biomedical Research, Harvard Medical School, Boston, Massachusetts

Aravin, AleXeI, Cold Spring Harbor Laboratory, Cold Spring Harbor, New York

BAK, MADs, Dept. of Medical Biochemistry and Genetics, Panum Institute, University of Copenhagen, Copenhagen, Denmark

BALZER, ErICA, Dept. of Molecular Biology, School of Medicine, University of Medicine and Dentistry of New Jersey

BANFI, SANDRO, Telethon Institute of Genetics and Medicine, Fondazione Telethon, Naples, Italy
BArbash, ZoHAR, Dept. of Hemato-Oncology, Sheba Medical Center, Tel Aviv University, Ramat Gan, Israel

BARFORD, DAVID, Section of Structural Biology, Chester Beatty Laboratories, Institute of Cancer Research, London, United Kingdom

Barta, Andrea, Max F. Perutz Laboratories, Medical University of Vienna, Vienna, Austria

BARTEL, DAVID, Dept. of Biology, Howard Hughes Medical Institute, Whitehead Institute, Massachusetts Institute of Technology, Cambridge, Massachusetts

BAss, BrendA, Dept. of Biochemistry, Howard Hughes Medical Institute, School of Medicine, University of Utah, Salt Lake City

BATEY, RoBert, Dept. of Chemistry and Biochemistry, University of Colorado, Boulder

BAulcombe, DAvid, Sainsbury Laboratory, John Innes Centre, Norwich, United Kingdom

BÄURLE, IsABEL, Dept. of Cell and Developmental Biology, John Innes Centre, Norwich, United Kingdom

BeAZley, Kim, Dept. of Agricultural Biotechnology, Monsanto, Chesterfield, Missouri

BeEmon, Karen, Dept. of Biology, Johns Hopkins University, Baltimore, Maryland

Berezikov, Eugene, Dept. of Functional Genomics, Hubrecht Laboratory, Utrecht, The Netherlands

Bernards, RenÉ, Dept. of Molecular Carcinogenesis, Netherlands Cancer Institute, Amsterdam, The Netherlands

Bernhoff, Eva, Dept. of Microbiology and Infectious Control, University Hospital of North Norway, Tromsø, Norway

Bernstein, Emily, Lab. of Chromatin Biology, Rockefeller University, New York, New York

BhatTacharyya, SuvendRA, Dept. of Epigenetics, Friedrich Miescher Institute for Biomedical Research, Basel, Switzerland

BIElke, Wolfgang, Dept. of Cell Biology, QIAGEN GmbH, Hilden, Germany

Biemar, Frederic, Dept. of Molecular and Cell Biology, University of California, Berkeley

Blackburn, Elizabeth, Dept. of Biochemistry and Biophysics, University of California, San Francisco

BOBEK, JAN, Institute of Microbiology, Czech Academy of Sciences, Prague, Czech Republic

Boccara, Martine, Unité de Recherche en Génétique Végétale, Atelier de BioInformatique, Université Paris, Evry, France

Borel, Christelle, Dept. of Genetic Medicine and Development, University of Geneva Medical School, Geneva, Switzerland

BouHouch, Khaled, Laboratoire de Génétique Moléculaire, Unité Mixte de Recherche, Centre National de la 
Recherche Scientifique, Ecole Normale Supérieure, Paris, France

Bowden, Michaela, Dept. of Genome and Proteome Sciences, Novartis Institute for Biomedical Research, Cambridge, Massachusetts

Bozzoni, Irene, Dept. of Genetics and Molecular Biology, University of Rome, La Sapienza, Rome, Italy

Brizuela, LeOnARdo, Dept. of Life Sciences and Chemical Analysis, Agilent Technologies, Cambridge, Massachusetts

Brock, GraHAM, Cancer Center, Ordway Research Institute, Albany, New York

BüHLER, MarC, Dept. of Cell Biology, Harvard Medical School, Boston, Massachusetts

Buker, Shane, Dept. of Cell Biology, Harvard Medical School, Boston, Massachusetts

Bushell, Martin, School of Pharmacy, University of Nottingham, Nottingham, United Kingdom

BusKIRK, Allen, Dept. of Chemistry and Biochemistry, Brigham Young University, Provo, Utah

Butler, Maurice, Dept. of Genetics, Harvard Medical School, Boston, Massachusetts

CAIKOVSKI, MARIAN, Department of Sciences, University of Geneva, Geneva, Switzerland

Calciano, Margaret, Dept. of Genetics and Developmental Biology, Health Center, School of Medicine, University of Connecticut, Farmington

Camiolo, Matthew, Cold Spring Harbor Laboratory, Cold Spring Harbor, New York

Carmell, Michelle, Cold Spring Harbor Laboratory, Cold Spring Harbor, New York

Carmichael, Gordon, Dept. of Genetics and Developmental Biology, Health Center, School of Medicine, University of Connecticut, Farmington

CARTHEW, Richard, Dept. of Biochemistry, Molecular and Cell Biology, Northwestern University, Evanston, Illinois

CAstoldi, Mirco, Dept. of Pediatric Oncology, Hematology and Immunology, Heidelberg University, Heidelberg, Germany

Cayota, Alfonso, Dept. of Medicine, Facultad de Medicina, Universidad de la República, Montevideo, Uruguay

$\mathrm{CECH}$, Thomas, Howard Hughes Medical Institute, Chevy Chase, Maryland

Cernilogar, Filippo, Dept. of Epigenetics and Genome Reprogramming, Dulbecco Telethon Institute, Institute of Genetics and Biophysics, Consiglio Nazionale delle Ricerche, Naples, Italy

Chalker, Douglas, Dept. of Biology, Washington University, St. Louis, Missouri

Chartrand, Pascal, Dept. of Biochemistry, Université de Montréal, Montréal, Québec, Canada

Chaves, DANIEL, Program in Molecular Medicine, Medical School, University of Massachusetts Worcester

Cheloufi, Sinem, Cold Spring Harbor Laboratory, Cold Spring Harbor, New York

Chen, Chun-Hong, Dept. of Biology, California Institute of Technology, Pasadena, California

CHEN, JACK, Cold Spring Harbor Laboratory, Cold Spring Harbor, New York

CHEN, JiCHAO, Dept. of Molecular Biology and Genetics, Johns Hopkins University, Baltimore, Maryland

Chen, Kevin, Dept. of Biology, Center for Comparative
Functional Genomics, New York University, New York

Chen, Xianming, Dept. of Biochemical and Molecular Biology, College of Medicine, Mayo Clinic, Rochester, Minnesota

ChookAJorn, Thanat, Dept. of Organismic and Evolutionary Biology, Harvard University, Cambridge, Massachusetts

Chou, Chen-Kung, Dept. of Life Science, Chang Gung University, Kwei-Shan, Tao-Yuan, Taiwan, Republic of China

Chow, Yen-Hung, Vaccine Research and Development Center, Taiwan National Health Research Institutes, Chu-Nan, Miao-Li, Taiwan, Republic of China

Ciaudo, Constance, Dept. of Development Biology, Centre National de la Recherche Scientifique, Pasteur Institute, Paris, France

Clark, Alejandra, The Wellcome Trust, Cancer Research UK Gurdon Institute, University of Cambridge, Cambridge, United Kingdom

Connell, Laureen, Genes \& Development, Cold Spring Harbor Laboratory Press, Woodbury, New York

COOKe, Robert, Stow, Massachusetts

CORTES-Cros, MARTA, Dept. of Platform and Chemical Biology, Novartis Institutes for Biomedical Research, Basel, Switzerland

CosTA, ANA, Warwick Horticultural Research International, University of Warwick, Warwick, United Kingdom

Coughlan, SEAn, Agilent Technologies, Wilmington, Delaware

Cullen, Bryan, Dept. of Genetics, Howard Hughes Medical Institute, Duke University, Durham, North Carolina

DAHLBERG, JAMES, Dept. of Biomolecular Chemistry, University of Wisconsin, Madison

DARnell, RoBert, Dept. of Molecular Neuro-Oncology, Howard Hughes Medical Institute, Rockefeller University, New York, New York

Daugherty, Matthew, Dept. of Biochemistry and Biophysics, University of California - San Francisco

Dawson, Elliott, BioVentures, Murfreesboro, Tennessee

DeGuire, Vincent, Dept. of Biochemistry, Université de Montréal, Montréal, Québec, Canada

DE Jong, Deborah, Dept. of Molecular and Cellular Biology, Harvard University, Cambridge, Massachusetts

DenLI, Ahmet, Lab. of Genetics, The Salk Institute, La Jolla, California

Diaz-Martinez, Laura, Dept. of Genetics, Cell Biology and Development, University of Minnesota, Minneapolis

DiBenedetto, Angela, Dept. of Biology, Villanova University, Villanova, Pennsylvania

DiK, WiLlem, Dept. of Immunology, Erasmus Medical Center, Rotterdam, The Netherlands

DING, YE, Dept. of Developmental Genetics and Bioinformatics, Wadsworth Center, Albany, New York

DITTMAR, KIMBERLY, Dept. of Biochemistry and Molecular Biology, University of Chicago, Chicago, Illinois

Dornan, David, Dept. of Molecular Oncology, Genentech, South San Francisco, California

DORNER, SILKE, Dept. of Molecular Biology and Genetics, School of Medicine, Johns Hopkins University, Baltimore, Maryland

Doudna, Jennifer, Dept. of Molecular and Cell Biology, Howard Hughes Medical Institute, University of California, Berkeley 
DREYFUSS, GIDEON, Dept. of Biochemistry and Biophysics, Howard Hughes Medical Institute, School of Medicine, University of Pennsylvania, Philadelphia

Dubowitz, Victor, Dept. of Paediatrics, Imperial College London, London, United Kingdom

Dumitru, Amalia, Dept. of Biology, FORTH, Institute of Molecular Biology and Biotechnology, Heraklion, Crete, Greece

Dus, MonicA, Cold Spring Harbor Laboratory, Cold Spring Harbor, New York

EBERT, MARGaret, Dept. of Biology, Massachusetts Institute of Technology, Cambridge, Massachusetts

EdDy, SEAN, Dept. of Genetics, Howard Hughes Medical Institute, School of Medicine, Washington University, St. Louis, Missouri

EgANA, ANA, Div. of RNA Biology, New England Biolabs, Ipswich, Massachusetts

Eggleston, Angela, Nature, Nature Publishing Group, Cambridge, Massachusetts

Ehm, Sebastian, Lab. of RNAi, Institute of Molecular Biotechnology, Vienna, Austria

Elliot, MARIE, Dept. of Biology, McMaster University, Hamilton, Ontario, Canada

ELMÉN, JOACIM, Dept. of Drug Disovery and Manufacturing, Santaris Pharma, Hørsholm, Denmark

Esau, Christine, Dept. of Antisense Drug Discovery, Isis Pharmaceuticals, Carlsbad, California

Esumi, Noriko, Dept. of Ophthalmology, School of Medicine, Johns Hopkins University, Baltimore, Maryland

FABIAN, Marc, Dept. of Biology, York University, Toronto, Ontario, Canada

Fagegaltier, Delphine, Dept. of Developmental Biology, Centre National de la Recherche Scientifique, Pasteur Institute, Paris, France

Faghini, Mohammad Ali, Dept. of Neurobiology, The Scripps Research Institute, Jupiter, Florida

Farabaugh, Philip, Dept. of Biological Sciences, University of Maryland, Baltimore

FEIG, ANDREW, Wayne State University, Detroit, Michigan

FELICE, KRISTIN, Dept. of Molecular, Microbial, and Structural Biology, Health Center, School of Medicine, University of Connecticut, Farmington

FERBEYRE, GERARDO, Dept. of Biochemistry, Université de Montréal, Montréal, Québec, Canada

Filipowicz, Witold, Dept. of Epigenetics, Friedrich Miescher Institute for Biomedical Research, Basel, Switzerland

Fischer, SylviA, Dept. of Molecular Biology, Massachusetts General Hospital, Harvard Medical School, Boston, Massachusetts

Flintoft, Louisa, Nature Reviews Genetics, Nature Publishing Group, London, United Kingdom

FontanA, LAURA, Dept. of Hematology, Oncology and Molecular Medicine, Istituto Superiore di Sanità, Rome, Italy

ForTIN, KRISTINE, Div. of Neuropathology, University of Pennsylvania, Philadelphia

Fox, RichARD, Dept. of Pathology, University of Washington, Seattle

Freeman, Katie, Dept. of Pathway Genomics, GlaxoSmithKline, Collegeville, Pennsylvania

FRENDEWEY, DAVID, Velocigene, Regeneron Pharmaceuti- cals, Tarrytown, New York

Frenster, JoHn, Activator RNA Research, Physicians' Educational Series, Atherton, California

Friedman, LiLACH, Dept. of Human Molecular Genetics and Biochemistry, Sackler School of Medicine, Tel Aviv University, Tel Aviv, Israel

FrITZ, BRIAN, Div. of Human Biology, Fred Hutchinson Cancer Research Center, Seattle, Washington

Gabel, Harrison, Dept. of Molecular Biology, Massachusetts General Hospital, Boston, Massachusetts

GANEM, Don, Dept. of Microbiology, Howard Hughes Medical Institute, University of California, San Francisco

Gann, Alexander, Cold Spring Harbor Laboratory Press, Woodbury, New York

GARY, SYDNEY, Banbury Center, Cold Spring Harbor Laboratory, Cold Spring Harbor, New York

Gaur, Rajesh, Dept. of Molecular Biology, Beckman Research Institute of the City of Hope, Duarte, California

GeORGEs, Michel, Dept. of Animal Genomics, University of Liège, Liège, Belgium

Ghoshal, Kalpana, Dept. of Molecular and Cellular Biochemistry, Ohio State University, Columbus, Ohio

GIEGERICH, ROBERT, Faculty of Technology, Bielefeld University, Bielefeld, Germany

GILadi, Hilla, Dept. of Gene Therapy, Hadassah University Hospital, Jerusalem, Israel

GILBERT, SunNY, Dept. of Chemistry and Biochemistry, University of Colorado, Boulder

GINGERAS, THOMAs, Transcription Mapping and Regulation Group, Affymetrix, Santa Clara, California

GiraldeZ, ANTONIO, Dept. of Molecular and Cellular Biology, Harvard University, Cambridge, Massachusetts

GIRARD, ANGEliQue, Cold Spring Harbor Laboratory, Cold Spring Harbor, New York

GLOVER-CuTTER, KIRA, Dept. of Biochemistry and Molecular Genetics, Health Sciences Center, University of Colorado, Aurora

GoFf, Loyal, Dept. of Cell and Developmental Biology, Rutgers University, Piscataway, New Jersey

GotTESMan, SusAn, Lab. of Molecular Biology, Center for Cancer Research, National Cancer Institute, National Institutes of Health, Bethesda, Maryland

Gottwein, Eva, Dept. of Molecular Genetics and Microbiology, Duke University, Durham, North Carolina

GRABOWSKI, PAULA, Dept. of Biological Sciences, University of Pittsburgh, Pittsburgh, Pennsylvania

GracheVA, Elena, Dept. of Biology, Washington University, St. Louis, Missouri

GrAVELEY, BrEnTON, Dept. of Genetics and Developmental Biology, Health Center, School of Medicine, University of Connecticut, Farmington

GreEN, RACHEL, Dept. of Molecular Biology and Genetics, Howard Hughes Medical Institute, School of Medicine, Johns Hopkins University, Baltimore, Maryland

Greider, CAROL, Dept. of Molecular Biology and Genetics, School of Medicine, Johns Hopkins University, Baltimore, Maryland

GREWAL, SHIV, Lab. of Molecular Cell Biology, National Cancer Institute, National Institutes of Health, Bethesda, Maryland

GreY, FinN, Dept. of Molecular Microbiology and Immunology, Oregon Health and Sciences University, Portland, Oregon 
Grimaud, Charlotte, Institute of Human Genetics, Centre National de la Recherche Scientifique, Montpellier, France

GrodzICKER, TERri, Cold Spring Harbor Laboratory Press, Woodbury, New York

Groisman, EduARdo, Dept. of Molecular Microbiology, Howard Hughes Medical Institute, School of Medicine, Washington University, St. Louis, Missouri

Groisman, Regina, Oncogenese, Differenciation et Transduction, Unité Propre de Recherche, Centre National de la Recherche Scientifique, Villejuif, France

GuIL, SoniA, Dept. of Chromosomes and Gene Expression, Medical Research Council Human Genetics Unit, Western General Hospital, Edinburgh, Scotland, United Kingdom

GundERSON, SAMuEL, Dept. of Molecular Biology and Biochemistry, Rutgers University, Piscataway, New Jersey

Gutierrez-Nava, Maria de la Luz, Dept. of Genetic Discovery, DuPont, Wilmington, Delaware

Haiser, Henry, Dept. of Biology, McMaster University, Hamilton, Ontario, Canada

Hale, CARYN, Dept. of Biochemistry and Molecular Biology, University of Georgia, Athens

Hammell, Christopher, Dept. of Biochemistry, Dartmouth Medical School, Hanover, New Hampshire

HAN, JinJu, School of Biological Sciences, Seoul National University, Seoul, South Korea

HANNON, GREGORY, Cold Spring Harbor Laboratory, Cold Spring Harbor, New York

Harvey, JagGer, Sainsbury Laboratory, John Innes Centre, Norwich, United Kingdom

Hatzigeorgiou, ARTEMIs, Dept. of Genetics, University of Pennsylvania, Philadelphia

HAVEcker, ErickA, Sainsbury Laboratory, John Innes Centre, Norwich, United Kingdom

HE, LIN, Cold Spring Harbor Laboratory, Cold Spring Harbor, New York

He, Xingyue, Cold Spring Harbor Laboratory, Cold Spring Harbor, New York

HEARD, DAVID, Dept. of Genomic Sciences Bioinformatics, Sanofi Aventis Pharma, Vitry-sur-Seine, France

HeARD, Edith, Mammalian Developmental Epigenetics Group, Unité Mixte de Recherche, Centre National de la Recherche Scientifique, Curie Institute, Paris, France

HeIDRICH, NADJA, AG Bacteriagenetik, Friedrich-Schiller University, Jena, Germany

Heimstaedt, Susanne, Sainsbury Laboratory, John Innes Centre, Norwich, United Kingdom

Henkin, Tina, Dept. of Microbiology, Ohio State University, Columbus, Ohio

HinAS, ANDREA, Dept. of Molecular Biology, Swedish University of Agricultural Sciences, Uppsala, Sweden

HIRSCH, Hans, Dept. of Clinical and Biological Sciences, University of Basel, Basel, Switzerland

Hobert, Oliver, Dept. of Biochemistry, Columbia University College of Physicians \& Surgeons, New York, New York

Hoechsmann, Matthias, Faculty of Technology, Bielefeld University, Bielefeld, Germany

Hong, Sun WoO, Dept. of Chemistry, School of Molecular Science, Pohang University of Science and Technology, Pohang, South Korea

HotтA, Ikuko, Cold Spring Harbor Laboratory, Cold
Spring Harbor, New York

Hu, Zonglin, Lab. of Bacterial Diseases, Bacterial Toxins and Therapeutics Section, National Institute of Allergy and Infectious Diseases, National Institutes of Health, Bethesda, Maryland

Huang, Julie, Dept of Molecular Biology, Massachusetts General Hospital, Harvard Medical School, Boston, Massachusetts

Hunter, Craig, Dept. of Molecular and Cellular Biology, Harvard University, Cambridge, Massachusetts

HuR, INHA, School of Biological Sciences, Seoul National University, Seoul, South Korea

HütTenhofer, AlexAnder, Div. of Genomics and RNomics, Innsbruck Biocenter, Innsbruck Medical University, Innsbruck, Austria

Hyun, SEogang, School of Biological Sciences, Seoul National University, Seoul, South Korea

IBARRA, INGRID, Cold Spring Harbor Laboratory, Cold Spring Harbor, New York

INGLIS, JoHN, Cold Spring Harbor Laboratory Press, Woodbury, New York

Irvine, DANiElle, Cold Spring Harbor Laboratory, Cold Spring Harbor, New York

IZAURRALDE, EliSA, Dept. of Biochemistry, Max-PlanckInstitute for Developmental Biology, Tübingen, Germany

JACOBSEn, Steve, Dept. of Molecular, Cell, and Developmental Biology, Howard Hughes Medical Institute, University of California, Los Angeles

JAn, CAlvin, Dept. of Biology, Whitehead Institute, Massachusetts Institute of Technology, Cambridge, Massachusetts

JAYASEnA, SumedHA, Dept. of Cancer Biology, Amgen, Thousand Oaks, California

JazDzewski, Krystian, Comprehensive Cancer Center, Ohio State University, Columbus, Ohio

JefFrIES, Clark, School of Pharmacy, University of North Carolina, Chapel Hill

Jensen, Kevin, Dept. of Molecular Biology and Biochemistry, Health Center, School of Medicine, University of Connecticut, Farmington

Ji, Xinjun, Department of Genetics, School of Medicine, University of Pennsylvania, Philadelphia

Johnston, Brian, Dept. of Pediatrics, School of Medicine, Stanford University, Stanford, California

Jorgensen, Richard, Dept. of Plant Sciences, University of Arizona, Tucson, Arizona

JoshuA-Tor, LeEmor, Cold Spring Harbor Laboratory, Cold Spring Harbor, New York

JovANOVIC, MARKo, Institute of Molecular Biology, University of Zürich, Zürich, Switzerland

Jozsi, Peter, Dept. of Gene Regulation, Invitrogen Life Technologies, Carlsbad, California

JuNG, JuN EuN, Dept. of Microbiology, University of Ulsan College of Medicine, Seoul, South Korea

Kalyna, MARIA, Institute of Medical Biochemistry, Medical University of Vienna, Vienna, Austria

Karginov, FedOR, Cold Spring Harbor Laboratory, Cold Spring Harbor, New York

Katayama, Shintaro, Lab. for Genome Exploration Research, Genomic Sciences Centre, RIKEN Yokohama Institute, Yokohama, Japan

KAUPPINEN, SAKARI, Dept. of Medical Biochemistry and 
Genetics, University of Copenhagen, Copenhagen, Denmark

KAWANO, MitsuOKI, National Institute of Child Health and Human Development, National Institutes of Health, Bethesda, Maryland

KenNeDy, ScotT, Dept. of Pharmacology, University of Wisconsin, Madison

Kiermer, Veronique, Nature Methods, Nature Publishing Group, New York, New York

KIM, DANIEL, Dept. of Molecular Biology, Beckman Research Institute of the City of Hope, Duarte, California

KIM, V. NARRY, School of Biological Sciences, Seoul National University, Seoul, South Korea

KIM, YounG-KooK, School of Biological Sciences, Seoul National University, Seoul, South Korea

Kishore, SHIVENDRA, Institute for Biochemistry, University of Erlangen, Erlangen, Germany

KISS, TAmÁs, Laboratoire de Biologie Moléculaire Eucaryote, Centre National de la Recherche Scientifique, Toulouse, France

Klattenhoff, Carla, Program in Molecular Medicine, Medical School, University of Massachusetts, Worcester

Klausen, MikKel, Dept. of Clinical Biochemistry, Rigshospitalet, University of Copenhagen, Copenhagen, Denmark

Ko, JAE-HYEONG, Dept. of Molecular, Cellular, and Developmental Biology, Yale University, New Haven, Connecticut

Konforti, Boyana, Nature Structural \& Molecular Biology, Nature Publishing Group, New York, New York

Kong, Yi Wen, School of Pharmacy, University of Nottingham, Nottingham, United Kingdom

Konstantinova, Pavlina, Dept. of Human Retrovirology, Academic Medical Center, University of Amsterdam, Amsterdam, The Netherlands

KozU, TomoKo, Research Institute for Clinical Oncology, Saitama Cancer Center, Saitama, Japan

Kumar, Madhu, Dept. of Biology, Center for Cancer Research, Massachusetts Institute of Technology, Cambridge, Massachusetts

KurodA, Mitzi, Harvard-Partners Center for Genetics and Genomics, Harvard University, Boston, Massachusetts

KuzNetsov, Vladimir, Institute for Mathematical Sciences, Genome Institute of Singapore, Singapore, Republic of Singapore

LAI, ERIC, Dept. of Developmental Biology, Sloan-Kettering Institute, New York, New York

LAMBERTZ, IRINA, Dept. of Molecular Biomedical Research, Flanders Interuniversity Institute for Biotechnology, Ghent University, Ghent, Belgium

LANDTHALER, MARKUS, Dept. of RNA Molecular Biology, Rockefeller University, New York, New York

LAPIDOS, KAREN, Dept. of Biochemistry, Molecular and Cellular Biology, Northwestern University, Evanston, Illinois

LAU, Nelson, Dept. of Molecular Biology, Massachusetts General Hospital, Boston, Massachusetts

LeChMan, Eric, Dept. of Cell and Molecular Biology, University Health Network, Toronto, Ontario, Canada

LEE, DONG-KI, Dept. of Chemistry, School of Molecular Science, Pohang University of Science and Technology, Pohang, South Korea

LEE, HeUIRAN, Dept. of Microbiology, University of Ulsan College of Medicine, Seoul, South Korea
LeE, JeAnNIE, Dept. of Molecular Biology, Massachusetts General Hospital, Harvard Medical School, Boston, Massachusetts

LEPÈRE, GERSENDE, Laboratoire de Génétique Moléculaire, Unité Mixte de Recherche, Centre National de la Recherche Scientifique, Ecole Normale Supérieure, Paris, France

Leung, Anthony, Center for Cancer Research, Massachusetts Institute of Technology, Cambridge, Massachusetts

Li, Chenguian, Dept. of Biochemistry and Molecular Pharmacology, Medical School, University of Massachusetts, Worcester

LI, LONG-CHENG, Dept. of Urology, University of California, San Francisco

LI, PAN, Dept. of Chemistry, University of California, Berkeley

LiAng, Chen, Dept. of Medicine, Lady Davis Institute, Jewish General Hospital, Montréal, Québec, Canada

LIPOVICH, LEONARD, Dept. of Information and Mathematical Sciences, Genome Institute of Singapore, Singapore, Republic of Singapore

LIU, JiDONG, Cold Spring Harbor Laboratory, Cold Spring Harbor, New York

LORENZ, Christina, Dept. of Biochemistry, University of Vienna, Vienna, Austria

Lou, HuA, Dept. of Genetics, Case Western Reserve University, Cleveland, Ohio

LUND, ELSEBET, Dept. of Biomolecular Chemistry, University of Wisconsin, Madison

Lussier, JACQues, Dept. of Biomedicine, Animal Reproduction Research Center, Université de Montréal, SaintHyacinthe, Québec, Canada

MA, Jin-BIAO, Structural Biology Program, Memorial Sloan-Kettering Cancer Center, New York, New York

MACARI, MARISA, Cold Spring Harbor Laboratory, Cold Spring Harbor, New York

MACRAE, IAN, Dept. of Molecular and Cell Biology, University of California, Berkeley

MAHER, CHristopher, Dept. of Biomedical Engineering, State University of New York, Stony Brook

MaITY, Tuhin, Dept. of Chemistry, University of North Carolina, Chapel Hill

Makeyev, Eugene, Dept of Molecular and Cellular Biology, Harvard University, Cambridge, Massachusetts

Maniataki, Elisavet, Dept. of Pathology, University of Pennsylvania, Philadelphia

MARAIA, RICHARD, Lab. of Molecular Growth Regulation, National Institutes of Health, Bethesda, Maryland

MARTIENSSEN, RoBERT, Cold Spring Harbor Laboratory, Cold Spring Harbor, New York

MATSKeVICH, AlEXEY, Institute of Medical Virology, University of Zürich, Zürich, Switzerland

MATTICK, JoHN, Institute for Molecular Bioscience, University of Queensland, St. Lucia, Brisbane, Australia

Mattie, Michael, Dept. of Quantitative Expression, Glaxo SmithKline, Research Triangle Park, North Carolina

Matukumalli, LAKShMi, Dept. of Bioinformatics and Computational Biology, George Mason University, Manassas, Virginia

MATZKE, MARJORI, Gregor Mendel Institute of Molecular Plant Biology, Austrian Academy of Sciences, Vienna, Austria 
MazureK, Anthony, Cold Spring Harbor Laboratory, Cold Spring Harbor, New York

McMullan, Laura, Dept. of Virology and Infectious Disease, Rockefeller University, New York, New York

McSwiggen, James, Dept. of Biochemistry and Bioinformatics, Nastech Pharmaceutical, Bothell, Washington

Megraw, Molly, Dept. of Genetics, Genomics and Computational Biology Graduate Group, University of Pennsylvania, Philadelphia

Mehle, Andrew, Dept. of Molecular and Cell Biology, Howard Hughes Medical Institute, University of California, Berkeley

Meister, GunTer, Dept. of RNA Biology, Max-PlanckInstitute for Biochemistry, Munich, Germany

MEYER, ERIC, Laboratoire de Génétique Moléculaire, Centre National de la Recherche Scientifique, Ecole Normale Supérieure, Paris, France

MiCA, ERICA, Dept. of Biomolecular Sciences and Biotechnology, University of Milan, Milan, Italy

Michalik, Steve, Dept. of Research and Development, Sigma Aldrich, St. Louis, Missouri

Mills, Nicholas, Dept. of Chemistry and Chemical Biology, University of California, San Francisco

Miriami, ElanA, Dept. of Genetics, The Hebrew University of Jerusalem, Jerusalem, Israel

Mischo, HannaH, Sir William Dunn School of Pathology, University of Oxford, Oxford, United Kingdom

MoAzed, DANEsh, Dept. of Cell Biology, Harvard Medical School, Boston, Massachusetts

Moelling, Karin, Institute of Medical Virology, University of Zürich, Zürich, Switzerland

Moore, Troy, Open Biosystems, Hudson Alpha Institute for Biotechnology, Huntsville, Alabama

Morillon, Antonin, Centre de Génétique Moléculaire, Centre National de la Recherche Scientifique, Gif-surYvette, France

Morita, TeppeI, Div. of Biological Science, Graduate School of Science, Nagoya University, Nagoya, Japan

Morris, Kevin, Dept. of Molecular and Experimental Medicine, The Scripps Research Institute, La Jolla, California

Moschenross, DARCy, Center for Vascular Biology, School of Medicine, University of Connecticut, Farmington

MuEnchow, SonJA, Adolf-Butenandt-Institute, Ludwig Maximilians University, Munich, Germany

Mullinax, BECKY, Dept. of Research and Development, Stratagene, La Jolla, California

Murchison, ElizABETH, Cold Spring Harbor Laboratory, Cold Spring Harbor, New York

Newman, Martin, Dept. of Cell and Developmental Biology, University of North Carolina, Chapel Hill

Ng Kwang Loon, Stanley, Dept. of Systems Biology, Bioinformatics Institute, Singapore, Republic of Singapore

Nilsen, Timothy, Center for RNA Molecular Biology, Case Western Reserve University, Cleveland, Ohio

OBERNOSTERER, GREGOR, Lab. of RNAi, Institute of Molecular Biotechnology, Vienna, Austria

Ochsenreiter, Torsten, Global Infectious Disease Program, Marine Biological Laboratory, Woods Hole, Massachusetts
OHLson, Johan, Dept. of Molecular Biology and Functional Genomics, Stockholm University, Stockholm, Sweden

Ohman, Marie, Dept. of Molecular Biology and Functional Genomics, Stockholm University, Stockholm, Sweden

Oono, Kiyoharu, Research Center for Environmental Genomics, Kobe University, Kobe, Japan

Orlando, VAlERIO, Dept. of Epigenetics and Genome Reprogramming, Dulbecco Telethon Institute, Institute of Genetics and Biophysics, Consiglio Nazionale delle Ricerche, Naples, Italy

Packer, Alan, Nature Genetics, Nature Publishing Group, New York, New York

PADAlON, Gilly, Dept. of Molecular Genetics and Biotechnology, The Hebrew University-Hadassah Medical School, Jerusalem, Israel

PAN, TAO, Dept. of Biochemistry and Molecular Biology, University of Chicago, Chicago, Illinois

PARK, Seung-Won, Dept. of Cell Biology and Molecular Medicine, University of Medicine and Dentistry of New Jersey, Newark

PARK, Sung-YeOn, School of Biological Sciences, Seoul National University, Seoul, South Korea

PARKER, JAMES, Section of Structural Biology, The Institute of Cancer Research, London, United Kingdom

PAROO, ZAIN, Dept. of Biochemistry, Southwestern Medical Center, University of Texas, Dallas

PARRotT, ANDREW, Dept. of Biochemistry, University of Medicine and Dentistry of New Jersey, Newark

PARRY, DEVIN, Dept. of Molecular Biology, Massachusetts General Hospital, Harvard Medical School, Boston, Massachusetts

PATEl, Dinshaw, Dept. of Structural Biology, Memorial Sloan-Kettering Cancer Center, New York, New York

PATEL, REKHA, Dept. of Biological Sciences, University of South Carolina, Columbia

PAtton, James, Dept. of Molecular Biology, Vanderbilt University, Nashville, Tennessee

PAWLICKI, JAN, Dept. of Pharmacology, Yale University, New Haven, Connecticut

PAZ, Nurit, Dept. of Genetics, Sheba Medical Center, TelAviv University, Ramat-Gan, Israel

Pedersen, JAKOB, School of Engineering, Center for Biomolecular Science and Engineering, Santa Cruz, California

Pennell, Roger, Dept. of Trait Development, Ceres, Thousand Oaks, California

Perkins, John, Dept. of Biotechnology Research and Development, DSM Nutritional Products, Basel, Switzerland

Perrimon, Norbert, Dept. of Genetics, Harvard Medical School, Boston, Massachusetts

Persson, HelenA, Dept. of Oncology, Lund University, Lund, Sweden

Peters, Lasse, Dept. of RNA Biology, Max-Planck-Institute for Biochemistry, Munich, Germany

Pezic, DubraVkA, Lab. of RNAi, Institute of Molecular Biotechnology, Vienna, Austria

PIKAARD, Craig, Dept. of Biology, Washington University, St. Louis, Missouri

Plasterk, Ronald, Dept. of Functional Genomics, 
Hubrecht Laboratory, Utrecht, The Netherlands

Poethig, Scott, Dept. of Biology, University of Pennsylvania, Philadelphia

Pollock, Mila, Cold Spring Harbor Laboratory Library, Cold Spring Harbor, New York

Prasanth, Kannanganattu, Cold Spring Harbor Laboratory, Cold Spring Harbor, New York

Prasanth, SuPRIYA, Cold Spring Harbor Laboratory, Cold Spring Harbor, New York

PresnaIl, JAmes, Dept. of Agriculture and Nutrition, DuPont Pioneer Hi-Bred International, Wilmington, Delaware

Proudfoot, Nicholas, Sir William Dunn School of Pathology, University of Oxford, Oxford, United Kingdom

QI, YiJun, Cold Spring Harbor Laboratory, Cold Spring Harbor, New York

RajewsKy, Nikolaus, Dept. of Biology, Center for Comparative Functional Genomics, New York University, New York

Rapicavoli, Nicole, Dept. of Neuroscience, School of Medicine, Johns Hopkins University, Baltimore, Maryland

RASMUSSEN, SoREN, Dept. of Research and Development, Exiqon, Vedbaek, Denmark

Rebatchouk, DMitri, Dept. of Bioinformatics, SanofiAventis, Bridgewater, New Jersey

Rechavi, GideOn, Cancer Research Center, Sheba Medical Center, Tel Hashomer, Israel

REDDI, PRABU, Dept. of Pathology, University of Virginia, Charlottesville

ReHMSMEIER, MARC, Center for Biotechnology, Bielefeld University, Bielefeld, Germany

Reijns, Martin, Wellcome Trust Centre for Cell Biology, University of Edinburgh, Edinburgh, Scotland, United Kingdom

Reinke, Catherine, Dept. of Biology, Carleton College, Northfield, Minnesota

REIS, EdUARDO, Dept. of Biochemistry, University of São Paulo, São Paulo, Brazil

RichARD, PATRICIA, Laboratoire de Biologie Moléculaire Eucaryote, Centre National de la Recherche Scientifique, Toulouse, France

Riddihough, GuY, Science, Science Magazine, Washington, D.C.

Rigoutsos, Isidore, Dept. of Bioinformatics and Pattern Discovery, IBM T.J. Watson Research Center, Yorktown Heights, New York

RinALDO, CHRISTINE, Dept. of Microbiology and Infectious Control, University Hospital of North Norway, Tromsø, Norway

Rivas, FABIOLA, Cold Spring Harbor Laboratory, Cold Spring Harbor, New York

Rodriguez, Antony, Lab. of Mouse Genomics, The Wellcome Trust Sanger Institute, Cambridge, United Kingdom

Rogler, Charles, Dept. of Medicine, Albert Einstein College of Medicine, Bronx, New York

Romfo, Charles, Dept. of Discovery, PTC Therapeutics, South Plainfield, New Jersey

Rounbehler, Robert, Dept. of Biochemistry, St. Jude Children's Research Hospital, Memphis, Tennessee
Rovira, CARlos, Dept. of Oncology, Lund University, Lund, Sweden

Ruvkun, Gary, Dept. of Molecular Biology, Massachusetts General Hospital, Harvard Medical School, Boston, Massachusetts

SACCHI, Nicoletta, Dept. of Cancer Genetics, Roswell Park Cancer Institute, Buffalo, New York

Sachs, Alan, Dept. of Molecular Profiling, Rosetta Inpharmatics, Merck Research Laboratories, Seattle, Washington

Saleh, Maria Carla, Dept. of Microbiology and Immunology, University of California, San Francisco

SAlotTi, JACQUEline, Dept. of Biochemistry, Institute of Chemistry, University of São Paulo, São Paulo, Brazil

SAlzman, David, Dept. of Molecular, Microbial, and Structural Biology, Center for Vascular Biology, Health Center, School of Medicine, University of Connecticut, Farmington

Sanbonmatsu, Kevin, Dept. of Theoretical Biology and Biophysics, Los Alamos National Laboratory, Los Alamos, New Mexico

SANDER, CHris, Computational Biology Center, Memorial Sloan-Kettering Cancer Center, New York, New York

SANDVIK, KJERSTI, Dept. of Microbiology and Infectious Control, University Hospital of North Norway, Tromsø, Norway

SARnOw, PETER, Dept. of Microbiology and Immunology, School of Medicine, Stanford University, Stanford, California

Saugstad, Julie, R.S. Dow Neurobiology Laboratories, Legacy Research, Portland, Oregon

SchIER, AlEXANDER, Dept. of Molecular and Cellular Biology, Harvard University, Cambridge, Massachusetts

Schoenberg, Daniel, Dept. of Molecular and Cellular Biochemistry, Ohio State University, Columbus, Ohio

SchumACHER, HeIKO, Dept. of Plant Sciences, Institute of Molecular Biology and Biotechnology, Heraklion, Crete, Greece

SeBAT, JonAtHan, Cold Spring Harbor Laboratory, Cold Spring Harbor, New York

SeILA, Amy, Center for Cancer Research, Massachusetts Institute of Technology, Cambridge, Massachusetts

Serganov, Alexander, Dept. of Structural Biology, Memorial Sloan-Kettering Cancer Center, New York, New York

Sethupathy, Praveen, Dept. of Genetics, Center for Bioinformatics, University of Pennsylvania, Philadelphia

Seto, AnItA, Dept. of Molecular Biology, Massachusetts General Hospital, Harvard Medical School, Boston, Massachusetts

Sharma, CynThIA, Dept. of RNA Biology, Max-PlanckInstitute for Infection Biology, Berlin, Germany

Sharp, PhILlip, Center for Cancer Research, Massachusetts Institute of Technology, Cambridge, Massachusetts

SHAw, RoBerT, The Wellcome Trust, Cancer Research UK Gurdon Institute, University of Cambridge, Cambridge, United Kingdom

SheA, CATHY, Dept. of Research, New England Biolabs, Ipswich, Massachusetts

SHEFER, KINNERET, Dept. of Genetics, The Hebrew University of Jerusalem, Jerusalem, Israel 
Shibata, Kazuhiro, Dept. for Coordination Program of Science and Technology Projects, Japan Science and Technology Agency, Tokyo, Japan

Shields, Robert, Trends in Genetics, Current Trends, Elsevier Science, London, United Kingdom

SHIN, JiNwOOK, National Creative Research Initiative Center, Seoul National University, Seoul, South Korea

Shinohara, Fumikazu, BioFrontier Laboratories, Kyowa Hakko Kogyo Co., Tokyo, Japan

Sigova, Alla, Dept. of Biochemistry and Molecular Pharmacology, Medical School, University of Massachusetts, Worcester

SiJEN, TitiA, Dept. of Functional Genomics, Hubrecht Laboratory, Utrecht, The Netherlands

Sim, SoyeOng, Dept. of Cell Biology, Yale University School of Medicine, New Haven, Connecticut

Siolas, Despina, Cold Spring Harbor Laboratory, Cold Spring Harbor, New York

SIU, FAI, Dept. of Molecular and Cell Biology, University of California, Berkeley

Slack, Frank, Dept. of Molecular, Cellular and Developmental Biology, Yale University, New Haven, Connecticut

SMIt, MARIA, Genome Research, Cold Spring Harbor Laboratory Press, Woodbury, New York

Smits, Guillaume, Dept. of Developmental Genetics and Genomic Imprinting, The Babraham Institute, Cambridge, United Kingdom

SNyder, Michael, Dept. of Molecular, Cellular and Developmental Biology, Yale University, New Haven, Connecticut

SonenBerg, NAHUM, Dept. of Biochemistry, McGill University, Montréal, Québec, Canada

SoutscheK, JÜrgen, Alnylam Pharmaceuticals, Kulmbach, Germany

Spector, DAvid, Cold Spring Harbor Laboratory, Cold Spring Harbor, New York

StAmM, STEFAN, Institute for Biochemistry, University of Erlangen, Erlangen, Germany

Stein, Paula, Dept. of Biology, University of Pennsylvania, Philadephia

Steiner, Florian, Dept. of Functional Genomics, Hubrecht Laboratory, Utrecht, The Netherlands

STEITZ, JOAN, Dept. of Molecular Biophysics and Biochemistry, Yale University School of Medicine, New Haven, Connecticut

Stern, Bodo, Cell, Cell Press, Cambridge, Massachusetts

Stewart, DAVID, Meetings and Courses Programs, Cold Spring Harbor Laboratory, Cold Spring Harbor, New York

Stillman, Bruce, President and CEO, Cold Spring Harbor Laboratory, Cold Spring Harbor, New York

Storz, GiselA, Cell Biology and Metabolism Branch, National Institute of Child Health and Human Development, National Institutes of Health, Bethesda, Maryland

STRECK, RANDAL, Dept. of Investigative Developmental Toxicology, Pfizer, Groton, Connecticut

Stricker, Stefan, Max F. Perutz Laboratories, Institute for Microbiology and Genetics, Center for Molecular Medicine, University of Vienna, Vienna, Austria

SuESS, BEATRIX, Department of Microbiology, University of Erlangen, Erlangen, Germany
Suhasini, Avvaru, Centre for Cellular and Molecular Biology, Hyderabad, India

Sunwoo, HonguaE, Cold Spring Harbor Laboratory, Cold Spring Harbor, New York

Sussman, Hillary, Genome Research, Cold Spring Harbor Laboratory Press, Woodbury, New York

SYlVESTRE, YANNICK, Dept. of Biochemistry, Université de Montréal, Montréal, Québec, Canada

TAKEDA, HARUKO, Dept. of Genetics, University of Liège, Liège, Belgium

TERnS, MiCHAEL, Dept. of Biochemistry and Molecular Biology, University of Georgia, Athens

Theunissen, JAN-WiLlem, Nature Biotechnology, Nature Publishing Group, New York, New York

Theurkauf, William, Program in Molecular Medicine, Medical Center, University of Massachusetts, Worcester

Thomson, J. Michael, Dept. of Cell and Developmental Biology, University of North Carolina, Chapel Hill

TIAN, YUAN, Dept. of Structural Biology, Memorial SloanKettering Cancer Center, New York, New York

Timmermans, Marja, Cold Spring Harbor Laboratory, Cold Spring Harbor, New York

TOLIA, NIRAJ, Cold Spring Harbor Laboratory, Cold Spring Harbor, New York

TOPS, BASTIAAN, Dept. of Functional Genomics, Hubrecht Laboratory, Utrecht, The Netherlands

Toren, GinAT, Dept. of Human Molecular Genetics and Biochemistry, Sackler School of Medicine, Tel Aviv University, Tel Aviv, Israel

TrottA, Christopher, Dept. of Discovery, PTC Therapeutics, South Plainfield, New Jersey

Tsai, Hsin-Yue, Dept. of Molecular, Cellular and Developmental Biology, Ohio State University, Columbus, Ohio

TSAI, NIEN-PEI, Dept. of Pharmacology, University of Minnesota, Minneapolis

Tsirigos, ArISTOTELIS, Dept. of Bioinformatics, IBM Research, Astoria, New York

TsuKADA, KoJI, Dept. of Biotechnology, Osaka University, Osaka, Japan

Tu, KimBerLy, Dept. of Molecular Biology, Princeton University, Princeton, New Jersey

Tu, ZhiJian, Dept. of Biochemistry, Virginia Polytechnic Institute and State University, Blacksburg, Virginia

Tzertzinis, George, Dept. of Research, New England Biolabs, Ipswich, Massachusetts

Urban, Johannes, Dept. of RNA Biology, Max-PlanckInstitute for Infection Biology, Berlin, Germany

Ushida, ChISATo, Dept. of Biochemistry and Biotechnology, Hirosaki University, Hirosaki, Japan

Vagin, VAsily, Dept. of Biochemistry and Molecular Pharmacology, Medical School, University of Massachusetts, Worcester

VAN DER MeIJden, CARoline, Cold Spring Harbor Laboratory, Cold Spring Harbor, New York

VAN RiJ, Ronald, Dept. of Microbiology and Immunology, University of California, San Francisco

Vasudevan, ShobHa, Dept. of Molecular Biophysics and Biochemistry, Yale University School of Medicine, New Haven, Connecticut

VAughn, MatTHEw, Cold Spring Harbor Laboratory, Cold Spring Harbor, New York 
VIKESAA, JONAS, Dept. of Clinical Biochemistry, Rigshospitalet, University of Copenhagen, Copenhagen, Denmark

Vogel, JoerG, Dept. of RNA Biology, Max-Planck-Institute for Infection Biology, Berlin, Germany

Volfovsky, Natalia, Advanced Biomedical Computing Center, SAIC-Frederick, National Cancer Institute, Frederick, Maryland

Wachtmann, Tim, Cardiovascular Multimedia Information Network, Pfizer, Groton, Connecticut

Wade, Nicholas, The New York Times, Science Department, New York, New York

Wahlstedt, Helene, Dept. of Molecular Biology and Functional Genomics, Stockholm University, Stockholm, Sweden

Wang, Hui, Agilent Laboratories, Agilent Technologies, Palo Alto, California

WANG, I.-FAN, Neuroscience Research Institute, University of California, Santa Barbara,

WANG, JinHUA, Hartwell Center for Bioinformatics and Biotechnology, St. Jude Children's Research Hospital, Memphis, Tennessee

WARE, DoreEn, Cold Spring Harbor Laboratory, Cold Spring Harbor, New York

WEHNER, KAREN, Dept. of Microbiology and Immunology, School of Medicine, Stanford University, Stanford, California

Westerhout, Ellen, Dept. of Human Retrovirology, Academic Medical Center, University of Amsterdam, Amsterdam, The Netherlands

Whitmarsh, BARBARA, Center for Scientific Review, National Institutes of Health, Bethesda, Maryland

WINKLER, WADE, Dept. of Biochemistry, Southwestern Medical Center, University of Texas, Dallas

Wishart, William, Dept. of Genome and Proteome Sciences, Novartis Institutes for Biomedical Research, Basel, Switzerland

Witkowski, JAN, Banbury Center, Cold Spring Harbor Laboratory, Cold Spring Harbor, New York

WitTrup, ANDERS, Dept. of Oncology, Lund University, Lund, Sweden

Wolin, SAndra, Dept. of Cell Biology, Howard Hughes Medical Institute, Yale University School of Medicine, New Haven, Connecticut

Wollmann, Heike, Dept. of Molecular Biology, MaxPlanck-Institute for Developmental Biology, Tübingen, Germany

Womble, Kristie, Dept. of Innovative Projects, BioVentures, Murfreesboro, Tennessee

Wu, XiAOYUn, Dept. of Molecular Biology, Massachusetts General Hospital, Boston, Massachusetts

XU, Ning, Dept. of Medical Biochemistry and Microbiology, Uppsala University, Uppsala, Sweden

Xuan, Zhenyu, Cold Spring Harbor Laboratory, Cold
Spring Harbor, New York

YAO, GANG, Dept. of Biochemistry and Molecular Biology, University of New Hampshire, Durham

YAO, JIE, Dept. of Applied and Engineering Physics, Cornell University, Ithaca, New York

Yeo, GeNE, Crick-Jacobs Center for Computational and Theoretical Biology, The Salk Institute, La Jolla, California

YILDIRIM, EDA, Lab. of Signal Transduction, National Institute of Environmental Health Sciences, National Institutes of Health, Research Triangle Park, North Carolina

You, Shinyun, Center for the Study of Hepatitis C, Rockefeller University, New York, New York

Youngman, Elaine, Dept. of Molecular Biology and Genetics, School of Medicine, Johns Hopkins University, Baltimore, Maryland

YU, YAnG, Dept. of Biochemistry, RNA Center, Case Western Reserve University, Cleveland, Ohio

YU, ZHENBAO, Biotechnology Research Institute, National Research Council Canada, Montréal, Québec, Canada

Yuan, CHIH-CHI, Cold Spring Harbor Laboratory, Cold Spring Harbor, New York

YuAN, Yu-REN, Structural Biology Program, Memorial Sloan-Kettering Cancer Center, New York, New York

ZAmore, Phillip, Dept. of Biochemistry and Molecular Pharmacology, Medical School, University of Massachusetts, Worcester

ZATechKa, Steven, Dept. of Biochemistry, Howard Hughes Medical Institute, St. Jude Children's Research Hospital, Memphis, Tennessee

ZHANG, CHI, Dept. of Biochemistry and Molecular Biology, Massachusetts General Hospital, Harvard Medical School, Boston, Massachusetts

Zhang, Elisa, Dept. of Biochemistry, Molecular and Cellular Biology, Harvard University, Cambridge, Massachusetts

Zhang, Weiguo, Div. of Life Sciences, Lawrence Berkeley National Laboratory, Berkeley, California

Zhang, YinhuA, Dept. of Biochemistry and Parasitology, New England Biolabs, Ipswich, Massachusetts

ZHANG, YUANJI, Dept. of Biochemistry and Bioinformatics, Monsanto, St. Louis, Missouri

ZhaO, Meng, Institute for Cell and Molecular Biology, University of Texas, Austin

ZHENG, ZHI-Ming, HIV and AIDS Malignancy Branch, National Cancer Institute, National Institutes of Health, Bethesda, Maryland

ZHOU, QIANG, Dept. of Biochemistry, Molecular and Cell Biology, University of California, Berkeley

ZHOU, RUI, Dept. of Biochemistry and Genetics, Harvard Medical School, Watertown, Massachusetts

ZIEve, Gary, Dept. of Biochemistry and Pathology, State University of New York, Stony Brook 

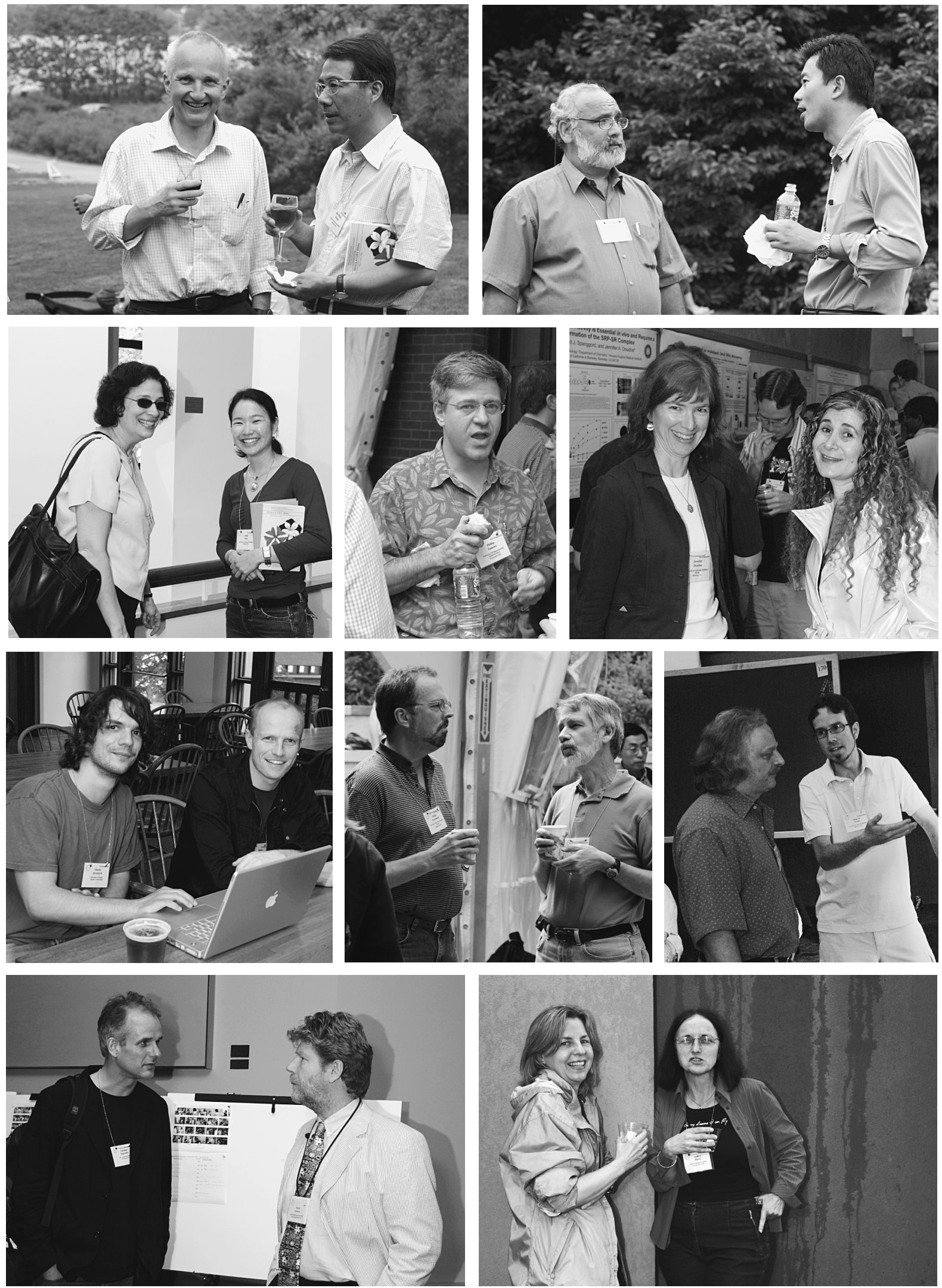

First row: P. Aman, Z.-M. Zheng; R. Maraia, Q. Zhou

Second row: S. Wolin, A. Seto; P. Zamore; J. Doudna, L. Joshua-Tor

Third row: M. Jovanovic, M. Landthaler; P. Farabaugh, D. Schoenberg; P. Sarnow, A. Mehle

Fourth row: N. Rajewsky, D. Stewart; M. Matzke, A. Barta 

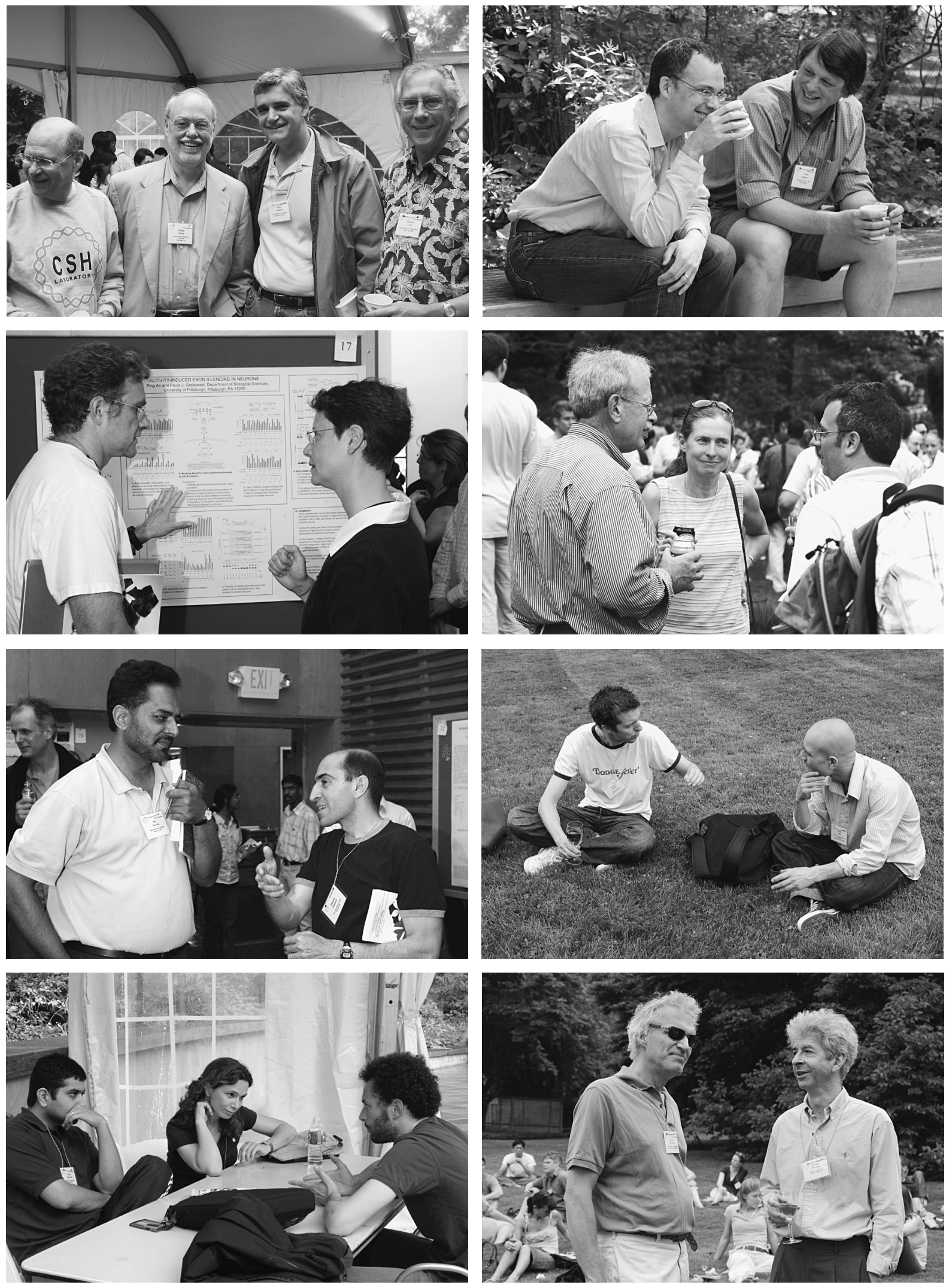

First row: N. Sonenberg, P. Sharp, B. Stillman, T. Cech; S. Eddy, C. Hunter Second row: S. Stamm, P. Grabowski; T. Nilsen, B. Bass, A. Feig Third row: S. Grewal, D. Moazed; J. Elmén, M. Bak

Fourth row: P. Sethupathy, A. Hatzigeorgiou, J. Brennecke; R. Bernards, R. Plasterk 

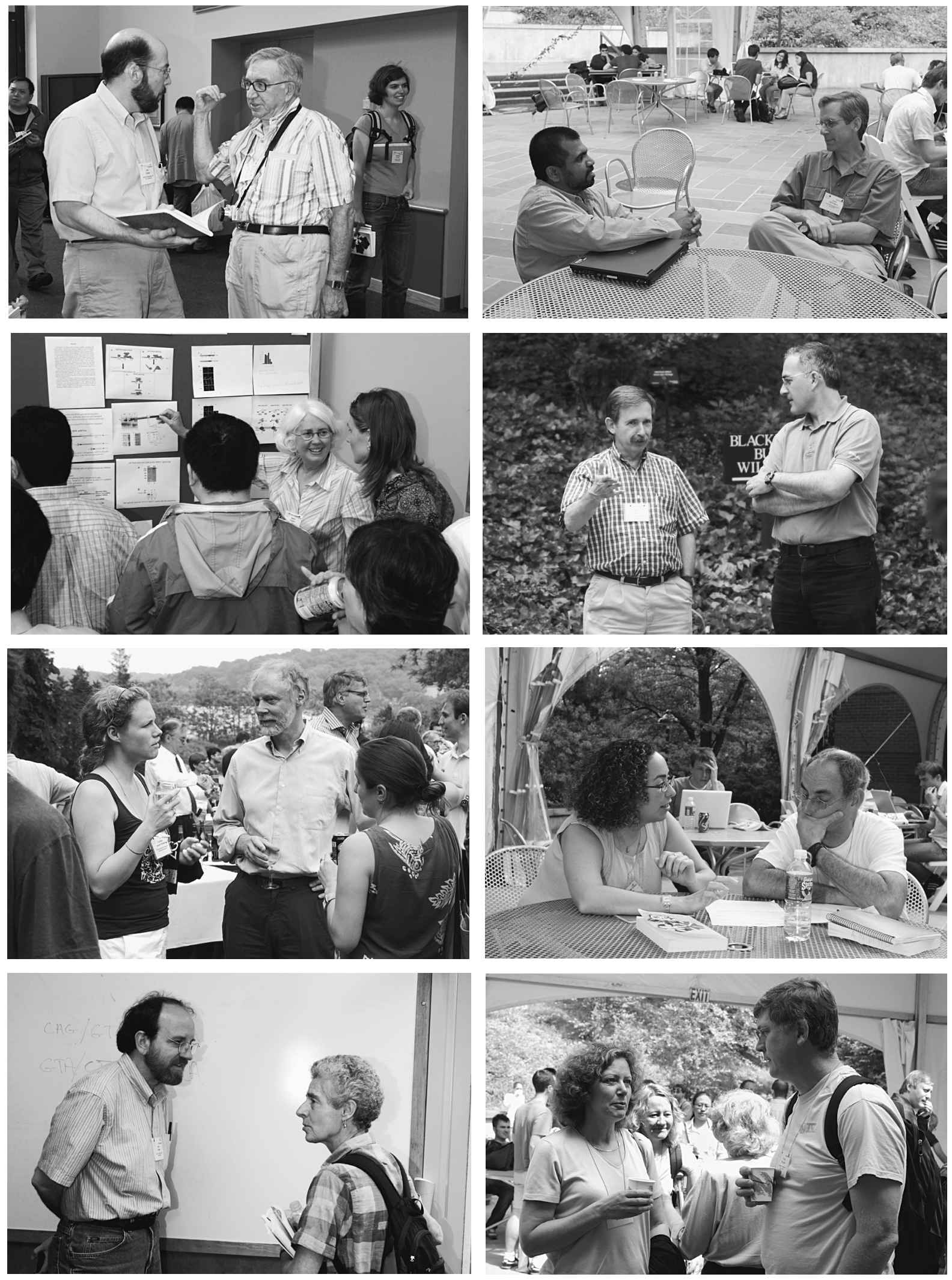

First row: J. Perkins, V. Dubowitz; S. Jayasena, J. McSwiggen

Second row: K. Beemon presenting her poster; G. Carmichael, A. Krainer Third row: C. van der Meijden, J. Inglis, S. Locke; M.C. Saleh, R. Andino

Fourth row: S. Poethig, E. Lund; B. Whitmarsh, C. Pikaard 

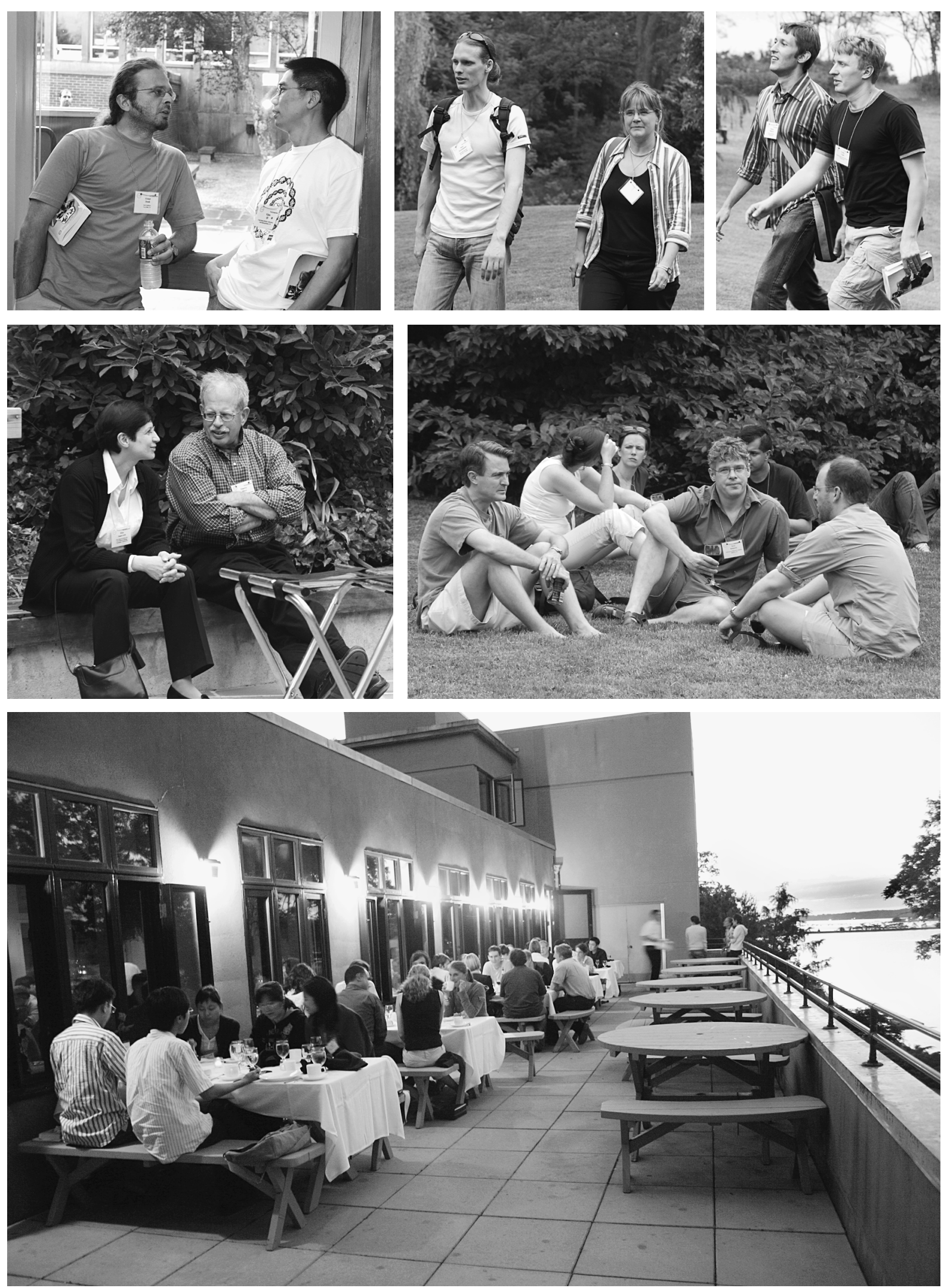

First row: A. Denli, Y. Qi; M. Rehmsmeier, B. Seuss; E. Makeyev, V. Vagin Second row: E. Izaurralde, T. Nilsen; F. Slack, S. Kennedy, C. Hammell Third row: Dining on the terrace overlooking Cold Spring Harbor 

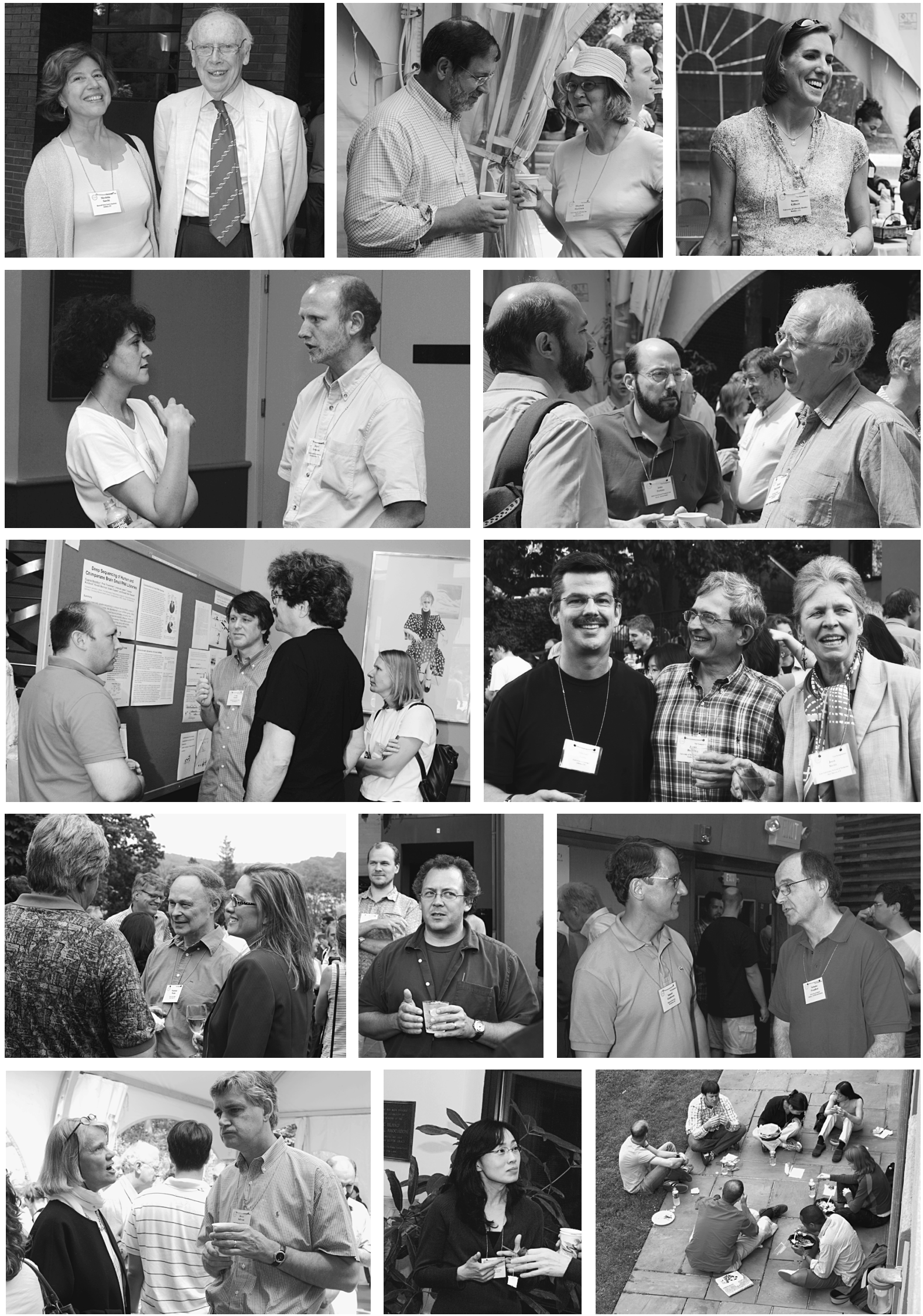

First row: N. Sacchi, J. Watson; J. Mattick, E. Blackburn; S. Gilbert

Second row: E. Heard, R. Martienssen; M. Snyder, J. Perkins, D. Baulcombe

Third row: E. Berezikov, C. Hunter, G. Ruvkun, C. Esau; M. Terns, J. Dahlberg, J. Steitz

Fourth row: J. Hicks, N. Wade, H. Sussman; G. Hannon; S. Gundersen, N. Proudfoot

Fifth row: K. Moelling, B. Stillman; V. Narry Kim; Lunch al fresco 

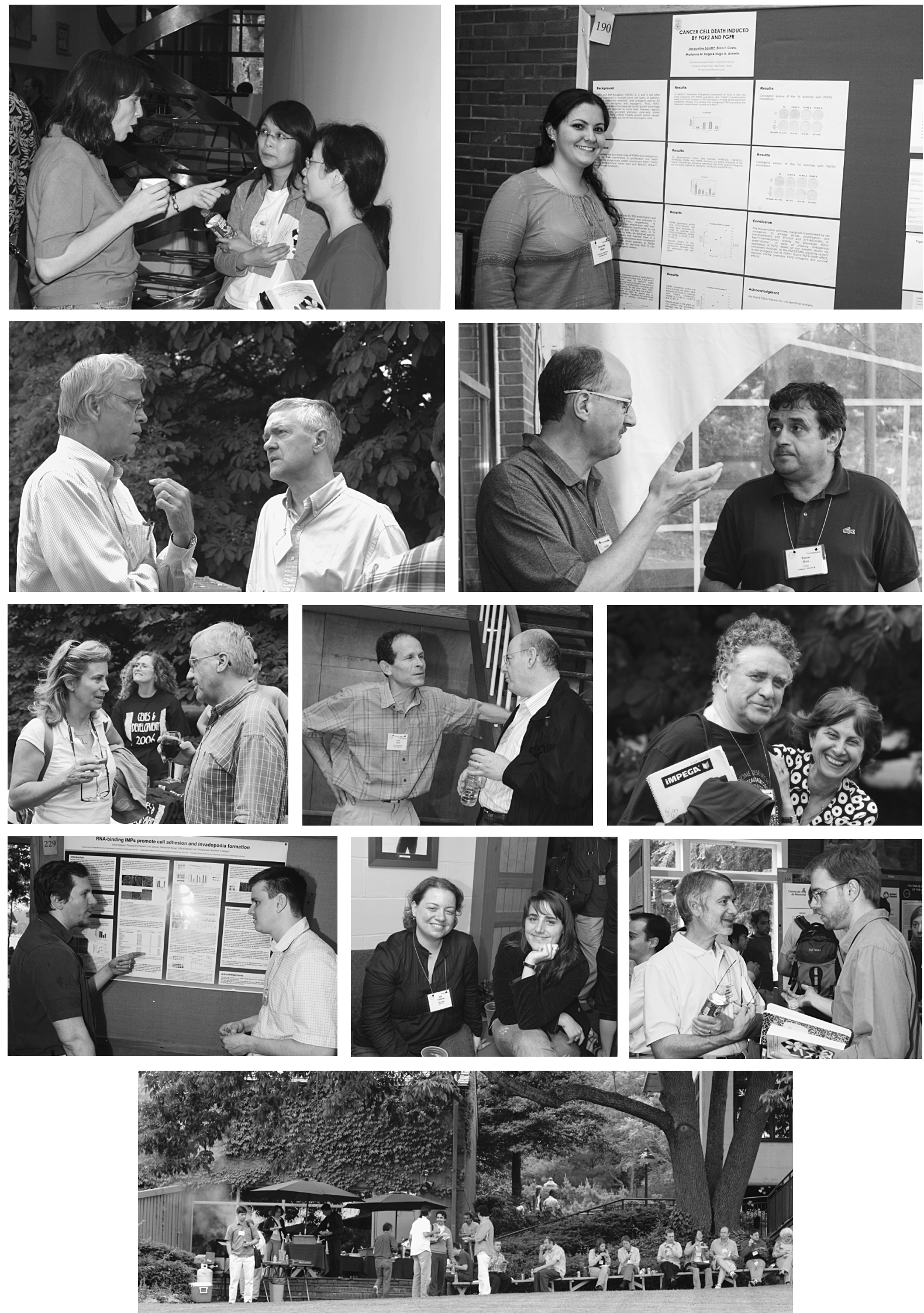

First row: M. Timmermans, L. Zhang, M. Guo; J. Salotti

Second row: E. Dawson, J. Witkowski; A. Hüttenhofer, T. Kiss

Third row: I. Bozzoni, W. Filipowicz; G. Zieve, G. Dreyfuss; R. Shields, M. Pollock

Fourth row: C. Trotta, J. Vikesaa; C. Borel, E. Yildirim; D. Schoenberg, W. Winkler

Ffth row: Picnic at Blackford 


\section{Foreword}

The role of DNA as the primary information carrier and RNA as the interpretative system for that information has been the key tenet of modern biology — the central dogma of molecular biology. This was modified by the discovery of reverse transcription and presented at this Symposium in 1970. The large majority of enzymatic reactions are carried out by proteins, although the discovery of catalytic RNA and its emerging centrality in certain highly conserved cellular processes such as protein synthesis and eukaryotic mRNA splicing have increasingly suggested that RNA plays a more diverse and complex role in the cell than initially proposed. The discovery of RNA interference and the ubiquity of microRNAs in diverse systems have clearly established that this polymer regulates gene transcription and translation in hitherto unexpected ways, as well as providing cellular defense mechanisms against viruses. How many of these regulatory processes are relics of an ancient RNA-based world, as has been suggested for the riboswitches, remains unclear, but their growing importance in both prokaryotic and eukaryotic biology is fuelling research and new ideas in laboratories around the world. Transcriptional and translational control by RNA, epigenetic phenomena such as RNA-directed DNA methylation and RNAi-directed heterochromatin formation, meiotic silencing, and cellular defense mechanisms against viruses are just some of the current areas under intense investigation through a variety of genetic, genomic, biochemical, cell biological, and structural approaches.

It was therefore deemed timely to focus the annual Symposium broadly on the theme of regulation of cellular processes by RNA-based mechanisms. It is increasingly clear that many of these processes may be harnessed to perturb biological function in a variety of biological systems, work that has reached its most widespread application with the use of large-scale RNAi screens. The Symposium therefore explored how the application of these technologies, combined with a growing understanding of the molecular basis of many of these processes, is yielding new insights into the treatment of many human diseases.

In organizing this Symposium with considerable help from Terri Grodzicker, we relied on the assistance of our colleagues Greg Hannon and Adrian Krainer for suggestions for speakers, while Susan Gottesman provided useful guidance in the prokaryotic field. We also thank the first evening speakers, Susan Gottesman, David Baulcombe, Gary Ruvkun, and Greg Hannon for providing an overview of the areas to be covered. This year's Reginald Harris Lecture was delivered by Elizabeth Blackburn on telomere ribonucleoprotein biology. We particularly thank Joan Steitz, with help from Greg Hannon, for delivering a thoughtful and realistic summary of the current state of the field, and Ronald Plasterk, who ably managed to convey the excitement and surprises of the emerging world of small RNAs in his Dorcas Cummings Lecture to the local community and the attending scientists.

This Symposium was attended by 469 scientists from over 25 countries, and the program included 70 oral presentations and 209 poster presentations. Essential funds to run this meeting were obtained from the National Cancer Institute, a branch of the National Institutes of Health. In addition, financial help from the corporate benefactors, sponsors, affiliates, and contributors of our meetings program is essential for these Symposia to remain a success, and we are most grateful for their continued support.

We thank Val Pakaluk and Mary Smith in the Meetings and Courses Program office for their efficient help in organizing the Symposium. Joan Ebert and Patricia Barker in the Cold Spring Harbor Laboratory Press, headed by John Inglis, ensured that this volume would be produced. We thank them for their dedication to producing high-quality publications.

Bruce Stillman David Stewart January 2007 


\section{Sponsors}

This meeting was funded in part by the National Cancer Institute, a branch of the National Institutes of Health.

Contributions from the following companies provide core support for the Cold Spring Harbor meetings program.

\section{Corporate Patron}

Pfizer, Inc.

\section{Corporate Benefactors}

Amgen, Inc.

Novartis Institutes for BioMedical Research

GlaxoSmithKline

\section{Corporate Sponsors}

Abbott Laboratories

Applied Biosystems

BioVentures, Inc.

Bristol-Myers Squibb Company

Diagnostic Products Corporation

Forest Laboratories, Inc.

GE Healthcare Bio-Sciences

Genentech, Inc.

Hoffmann-La Roche, Inc.

\section{Plant Corporate Associates}

ArborGen

Monsanto Company

Pioneer Hi-Bred International, Inc.

\section{Corporate Affiliates}

Abcam, Ltd.

Agilent Technologies

\section{Corporate Contributors}

Aviva Systems Biology

Bethyl Laboratories

Cell Signaling Technology

Epicentre Biotechnologies

Illumina

inGenious Targeting Laboratory, Inc.

IRx Therapeutics, Inc.

\section{Foundations}

Albert B. Sabin Vaccine Institute, Inc.

Hudson Alpha Institute for Biotechnology 


\section{Contents}

Symposium Participants

\section{Introduction}

Small RNA Regulators and the Bacterial Response to Stress S. Gottesman, C.A. McCullen, M. Guillier, C.K. Vanderpool, N. Majdalani, J. Benhammou, K.M. Thompson, P.C. FitzGerald, N.A. Sowa, and D.J. FitzGerald

Short Silencing RNA: The Dark Matter of Genetics? D.C. Baulcombe

Misexpression of the Caenorhabditis elegans miRNA let-7 Is Sufficient to Drive Developmental Programs G.D. Hayes and G. Ruvkun

Function and Localization of MicroRNAs in Mammalian Cells A.K.L. Leung and P.A. Sharp

\section{Mechanism and Biology of RNAi}

The RNAi Pathway Initiated by Dicer-2 in Drosophila K. Kim, Y.S. Lee, D. Harris, K. Nakahara, and R.W. Carthew

Molecular Mechanism of Target RNA Transcript Recognition by Argonaute-Guide Complexes J.S. Parker, S.M. Roe, and D. Barford

Drosha in Primary MicroRNA Processing Y. Lee, J. Han, K.-H. Yeom, H. Jin, and V.N. Kim

Substrate Selectivity of Exportin 5 and Dicer in the Biogenesis of MicroRNAs E. Lund and J.E. Dahlberg

The Argonautes L. Joshua-Tor

Structure of Dicer and Mechanistic Implications for RNAi I.J. MacRae, F. Li, K. Zhou, W.Z. Cande, and J.A. Doudna

Structural Biology of RNA Silencing and Its Functional Implications D.J. Patel, J.-B. Ma, Y.-R. Yuan, K. Ye, Y. Pei, V. Kuryavyi, L. Malinina, G. Meister, and T. Tuschl

Systemic RNAi in Caenorhabditis elegans C.P. Hunter, W.M. Winston, C. Molodowitch, E.H. Feinberg, J. Shih, M. Sutherlin, A.J. Wright, and M.C. Fitzgerald

\section{Genome-wide Approaches}

Transcriptional Landscape of the Human and Fly Genomes: Nonlinear and Multifunctional Modular Model of Transcriptomes A.T. Willingham, S. Dike, J. Cheng, J.R. Manak, I. Bell, E. Cheung, J. Drenkow, E. Dumais, R. Duttagupta, M. Ganesh, S. Ghosh, G. Helt, D. Nix, A. Piccolboni, V. Sementchenko, H. Tammana, P. Kapranov, the ENCODE Genes and Transcripts Group, and T.R. Gingeras

Novel Transcribed Regions in the Human Genome J. Rozowsky, J. Wu, Z. Lian, U. Nagalakshmi, J.O. Korbel, P. Kapranov, D. Zheng, S. Dyke, P. Newburger, P. Miller, T.R. Gingeras, S. Weissman, M. Gerstein, and M. Snyder

MicroRNAs in Search of a Target G. Stefani and F. Slack

RNomics: Identification and Function of Small Non-Protein-coding RNAs in Model Organisms A. Hüttenhofer

Drosophila Genome-wide RNAi Screens: Are They Delivering the Promise? B. Mathey-Prevot and N. Perrimon

Deep Conservation of MicroRNA-target Relationships and 3'UTR Motifs in Vertebrates, Flies, and Nematodes K. Chen and N. Rajewsky 


\section{Small RNAs in Development}

Organ Polarity in Plants Is Specified through the Opposing Activity of Two Distinct Small Regulatory RNAs F.T.S. Nogueira, A.K. Sarkar, D.H. Chitwood, and M.C.P. Timmermans

The Function of RNAi in Plant Development R.S. Poethig, A. Peragine, M. Yoshikawa, C. Hunter, M. Willmann, and G. Wu

asiRNAs, DNA Damage, and Embryonic Axis Specification W.E. Theurkauf, C. Klattenhoff, D.P. Bratu, N. McGinnis-Schultz, B.S. Koppetsch, and H.A. Cook

Architecture of a MicroRNA-controlled Gene Regulatory Network That Diversifies Neuronal Cell Fates O. Hobert

The Caenorhabditis elegans Argonautes ALG-1 and ALG-2: Almost Identical yet Different B.B.J. Tops, R.H.A. Plasterk, and R.F. Ketting

MicroRNA Function and Mechanism: Insights from Zebra Fish A.F. Schier and A.J. Giraldez

MicroRNAs and Hematopoietic Differentiation A. Fatica, A. Rosa, F. Fazi, M. Ballarino, M. Morlando, F.G. De Angelis, E. Caffarelli, C. Nervi, and I. Bozzoni

\section{Telomeres and Cancer}

Expression and Suppression of Human Telomerase RNA S. Li and E.H. Blackburn

RNA as a Flexible Scaffold for Proteins: Yeast Telomerase and Beyond D.C. Zappulla and T.R. Cech

Telomerase RNA Levels Limit the Telomere Length Equilibrium C.W. Greider

\section{End Regulation of Transcripts}

Sensing Metabolic Signals with Nascent RNA Transcripts: The T Box and S Box Riboswitches as Paradigms T.M. Henkin and F.J. Grundy

Genetic Control by cis-Acting Regulatory RNAs in Bacillus subtilis: General Principles and Prospects for Discovery Irnov, A. Kertsburg, and W.C. Winkler

$\mathrm{A} \mathrm{Mg}^{2+}$-responding RNA That Controls the Expression of a $\mathrm{Mg}^{2+}$ Transporter E.A. Groisman, M.J. Cromie, Y. Shi, and T. Latifi

Structural Studies of the Purine and SAM Binding Riboswitches S.D. Gilbert, R.K. Montange, C.D. Stoddard, and R.T. Batey

\section{RNPs and RNA Editing}

How Does RNA Editing Affect dsRNA-mediated Gene Silencing? B.L. Bass

How a Small DNA Virus Uses dsRNA but Not RNAi to Regulate Its Life Cycle $R$. $G u$,

$$
\text { Z. Zhang, and G.G. Carmichael }
$$

Regulation of Two Key Nuclear Enzymatic Activities by the 7SK Small Nuclear RNA W.-J. He, R. Chen, Z. Yang, and Q. Zhou

The SMN Complex: An Assembly Machine for RNPs D.J. Battle, M. Kasim, J. Yong, F. Lotti, C.-K. Lau, J. Mouaikel, Z. Zhang, K. Han, L. Wan, and G. Dreyfuss

\section{Biology of Short RNAs}

Measuring the Rates of Transcriptional Elongation in the Female Drosophila melanogaster Germ Line by Nuclear Run-on A. Sigova, V. Vagin, and P.D. Zamore

Polymorphic MicroRNA-Target Interactions: A Novel Source of Phenotypic Variation M. Georges, A. Clop, F. Marcq, H. Takeda, D. Pirottin, S. Hiard, X. Tordoir, F. Caiment, F. Meish, B. Bibé, J. Bouix, J.M. Elsen, F. Eychenne, E. Laville, C. Larzul, D. Milenkovic, J. Tobin, and C. Charlier

Expression and Function of MicroRNAs in Viruses Great and Small C.S. Sullivan, A. Grundhoff, S. Tevethia, R. Treisman, J.M. Pipas, and D. Ganem 
Expression and Function of MicroRNAs Encoded by Kaposi's Sarcoma-associated Herpesvirus E. Gottwein, X. Cai, and B.R. Cullen

Relationship between Retroviral Replication and RNA Interference Machineries K. Moelling, A. Matskevich, and J.-S. Jung

Positive and Negative Modulation of Viral and Cellular mRNAs by Liver-specific MicroRNA miR-122 C.L. Jopling, K.L. Norman, and P. Sarnow

\section{Control of Gene Expression by Noncoding RNAs}

The Challenge of Viral snRNPs N.K. Conrad, V. Fok, D. Cazalla, S. Borah, and J.A. Steitz

MSL Complex Associates with Clusters of Actively Transcribed Genes along the Drosophila Male X Chromosome E. Larschan, A.A. Alekseyenko, W.R. Lai, P.J. Park, and M.I. Kuroda

Biogenesis and Intranuclear Trafficking of Human Box C/D and H/ACA RNPs T. Kiss, E. Fayet, B.E. Jády, P. Richard, and M. Weber

RNA and Protein Actors in X-Chromosome Inactivation O. Masui and E. Heard

X-Chromosome Kiss and Tell: How the Xs Go Their Separate Ways M.C. Anguera, B.K. Sun, N. Xu, and J.T. Lee

\section{Heterochromatin}

Genetic Analyses of DNA Methyltransferases in Arabidopsis thaliana X. Zhang and S.E. Jacobsen

RNA-directed DNA Methylation and Pol IVb in Arabidopsis M. Matzke, T. Kanno, B. Huettel, L. Daxinger, and A.J.M. Matzke

Studies on the Mechanism of RNAi-dependent Heterochromatin Assembly D. Moazed, M. Bühler, S.M. Buker, S.U. Colmenares, E.L. Gerace, S.A. Gerber, E.-J.E. Hong, M.R. Motamedi, A. Verdel, J. Villén, and S.P. Gygi

Cell Biology of the Arabidopsis Nuclear siRNA Pathway for RNA-directed Chromatin Modification C.S. Pikaard

A Paragenetic Perspective on Integration of RNA Silencing into the Epigenome and Its Role in the Biology of Higher Plants R.A. Jorgensen, N. Doetsch, A. Müller, Q. Que, K. Gendler, and C.A. Napoli

RNAi-mediated Heterochromatin Assembly in Fission Yeast M. Zofall and S.I.S. Grewal

Slicing and Spreading of Heterochromatic Silencing by RNA Interference S.M. Locke and R.A. Martienssen

\section{Quality Control, Messenger RNA Turnover, and Translational Control}

Molecular Chaperones and Quality Control in Noncoding RNA Biogenesis S.L. Wolin and E.J. Wurtmann

Stress-induced Reversal of MicroRNA Repression and mRNA P-body Localization in Human Cells S.N. Bhattacharyya, R. Habermacher, U. Martine, E.I. Closs, and W. Filipowicz

MicroRNAs Silence Gene Expression by Repressing Protein Expression and/or by Promoting mRNA Decay I. Behm-Ansmant, J. Rehwinkel, and E. Izaurralde

MicroRNAs, mRNAs, and Translation P.A. Maroney, Y. Yu, and T.W. Nilsen

Regulation of Poly(A)-binding Protein through PABP-interacting Proteins M.C. Derry, A. Yanagiya, Y. Martineau, and N. Sonenberg

Two Distinct Conformations of the Conserved RNA-rich Decoding Center of the Small Ribosomal Subunit Are Recognized by tRNAs and Release Factors E.M. Youngman, L. Cochella, J.L. Brunelle, S. He, and R. Green

Summary: The Expanding Universe of Noncoding RNAs G.J. Hannon, F.V. Rivas, E.P. Murchison, and J.A. Steitz 


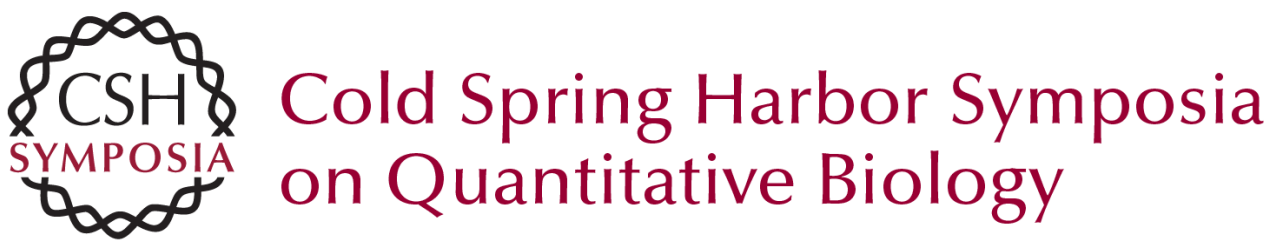

\section{Cold Spring Harbor Symposia On Quantitative Biology Volume Lxxi}

Cold Spring Harb Symp Quant Biol 2006 71: i-xxv

Access the most recent version at doi:10.1101/sqb.2006.71.067

\section{License}

Email Alerting Receive free email alerts when new articles cite this article - sign up in Service the box at the top right corner of the article or click here. 